\title{
E agora, Rio? 0 turismo pós-megaeventos
}

\author{
What now Rio? The tourism after megaevents \\ Y ahora, Rio? El turismo después de los megaeventos
}

http://dx.doi.org/10.18472/cvt.17n1.2017.1439

Roberto Bartholo 〈bartholo@pep.ufrj.br >

Editor chefe do Caderno Virtual de Turismo. Professor do Programa de Engenharia de Produção da COPPE da Universidade Federal do Rio de Janeiro (UFRJ), Rio de Janeiro, RJ, Brasil.

Ivan Bursztyn 〈ivan@gastronomia.ufrj.br >

Editor científico do Caderno Virtual de Turismo. Professor do curso de gastronomia da Universidade Federal do Rio de Janeiro (UFRJ), Rio de Janeiro, RJ, Brasil.

Aguinaldo Cesar Fratucci 〈acfratucci@gmail.com >

Editor científico do Caderno Virtual de Turismo. Professor do Programa de pós-graduação em Turismo da Universidade Federal Fluminense (UFF), Niterói, RJ, Brasil.

Luis Tadeu Assad 〈assadmar@iabs.org.br >

Editor científico do Caderno Virtual de Turismo. Diretor presidente do Instituto Brasileiro de Desenvolvimento e Sustentabilidade (IABS), Brasília, DF, Brasil.

FORMATO PARA CITAÇÃO DESTE ARTIGO

BARTHOLO, R.; BURSZTYN, I.; FRATUCCI, A.C.; ASSAD, L.T. 2016 o ano dos megaeventos esportivos e das grandes incertezas. Caderno Virtual de Turismo. Rio de Janeiro, v. 17, n. 1, p.810, abr. 2017.

REALIZAÇÃO

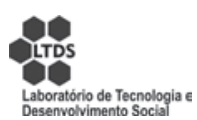

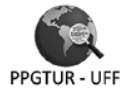

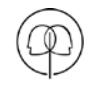

IABS
APOIO INSTITUCIONAL

COPPE

UFR]

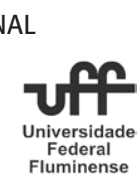

EDIÇÃO

PATROCÍNIO

IR⿴囗十⺝TS
(2) FAPER. 
O ano de 2016 marcou um dos momentos mais intensos do setor turístico do estado e da cidade do Rio de Janeiro e, indiretamente, de todo o país. A realização dos Jogos Olímpicos de Verão 2016 e dos Jogos Paralímpicos 2016 fecharam um ciclo de megaeventos na cidade do Rio de Janeiro, do qual se aguardava ansiosamente grandes legados materiais e imateriais para a cidade e para o estado. Nesse período, assistimos a realização dos XV Jogos Pan Americanos de 2007, dos Jogos Militares em 2011, da Conferência Internacional ONU Rio + 20 em 2012, da Jornada Mundial da Juventude (JMJ) em 2013, da Copa das Confederação de Futebol FIFA em 2013, da Copa do Mundo de Futebol Fifa em 2014 e, fechando o ciclo em 2016, das Olimpíadas e das Paralímpiadas.

O discurso neoliberal que domina a cena brasileira e internacional, desde meados da década de 1990 investiu todos seus recursos para seduzir os cariocas e fluminenses com promessas de legados de grande escala, para convence-los da necessidade e da urgência da cidade se abrir para sediar megaeventos internacionais, em sua grande maioria esportivos... E conseguiram seu intento, levando a cidade e o estado a assumirem compromissos financeiros elevados para atender aos cadernos de exigências das diversas entidades organizadoras daqueles megaeventos.

Quase sempre (para não afirmar que nunca) sem ouvir os cidadãos, planos e projetos mirabolantes foram sendo traçados, contratados e executados visando preparar a cidade para receber milhões de visitantes durante os megaeventos, com a promessas que isso elevaria a imagem do destino turístico no mercado internacional e garantiria a sua (re)inserção nos grandes fluxos de demandas atuais.

Durante os megaeventos a cidade recebeu muitos visitantes que se encantaram com o que lhes foi mostrado... Os eventos, de um modo geral, salvo algumas falhas e problemas que passaram quase desapercebidos do grande público, foram bem sucedidos e a cidade foi aplaudida pela imprensa nacional e internacional. Até às vésperas das Olímpiadas muitos não acreditavam que tudo iria estar pronto e, mais importante, funcionar regularmente. Mas, mais uma vez a cidade e o país surpreenderam a todos e tudo (ou quase tudo) funcionou.

Agora, passados alguns meses do último megaevento, a cidade se vê novamente às voltas com os números poucos animadores do setor turístico. A cidade, buscando atender a uma das muitas exigências do Comitê Olímpico Internacional, impulsionou a sua oferta de unidades habitacionais em meios de hospedagem: das cerca de 19.800 unidades habitacionais existentes na cidade em 2010, chegou-se a 37.000 unidades habitacionais em 2016. Quando somadas à oferta de unidades habitacionais em apart hotéis, albergues e motéis, esse número ultrapassou a marca de 51 mil quartos, muito acima da quantidade exigida pelo COI (40 mil uhs). A previsão inicial, segundo a Rio Negócios, era a cidade atingir a uma oferta total de 54.337 unidades habitacionais (FRATUCCI, SPOLON, TOMÉ MACHADO, 2016).

Segundo os dados da Associação Brasileira da Industria Hoteleira do Rio de Janeiro (ABIH-RJ), durante os Jogos Olímpicos a taxa de ocupação média dos hotéis da cidade ficou em torno de $96 \%$ (agosto de 2016), número considerado muito bom por todos. Entretanto, em novembro de 2016 a taxa de ocupação ficou em 52\%, bastante abaixo da taxa de ocupação do mês de novembro de 2015 (69\%), indicando um cenário de excesso de oferta e de pouco procura.

Tal questão da oferta de unidades habitacionais é apenas um exemplo que elegemos para comentar o panorama atual do turismo na cidade e no estado do Rio de Janeiro. Investiu-se muito para a captação e realização dos megaeventos, mas parece que pouco se investiu no planejamento do que iria acontecer no pós-eventos. Ouviu-se muito sobre os famosos legados que seriam deixados para a cidade, mas 
pouco ouviu-se sobre estratégias para manter e ampliar os fluxos de demanda de turistas para o país e, especialmente, para a cidade do Rio de Janeiro.

Sincronicamente à realização dos dois últimos megaeventos na cidade do Rio de Janeiro, o país entrou em uma grave crise política e institucional. O Estado do Rio de Janeiro, por sua vez, passou a enfrentar uma das maiores crises política, econômica e moral da sua história recente. A queda do preço do barril de petróleo diminuiu sistematicamente a arrecadação de impostos do governo estadual e, aliada à crise e escândalos de corrupções que se revelou maior que o esperado, levaram a um cenário quase de catástrofe para a população fluminense.

Para nós, pesquisadores e estudiosos do fenômeno e da atividade turística se impõe uma necessidade premente de pesquisas e estudos sobre tudo o que se desenrolou no principal destino turístico do país e, principalmente, a prospecção de cenários que está por vir.

A história recente nos revela que, de um modo geral, a estratégia de realização de megaeventos por parte de cidades para se inserirem de forma mais vigorosa no mercado turístico internacional, nos revela que, nem sempre deu bons frutos. Cidades como Atenas, Pequim, Atlanta, Sidney, ganharam muito com a realização dos megaeventos, mas também herdaram dívidas públicas significativas, além de legados nada positivos para suas populações.

Fica a pergunta: valeu a pena tanto investimento em infraestrutura e em equipamentos que agora estão praticamente abandonados, sem vida e exigindo mais investimentos para a sua demolição, remoção ou refuncionalização? Até que ponto a cidade anfitriã dos tais megaeventos se beneficia dos mesmos? E seus cidadãos, que a sustentam com seus impostos regulares e rotineiros, o que pensam disso? Se ouvidos previamente, após tomarem conhecimento dos detalhes dos investimentos que seriam exigidos, teriam concordado com a proposta?

\section{Referências:}

FRATUCCI, A.C.; SPOLON, A.P.G.; TOMÉ, M. O turismo no Rio de Janeiro: da tríade praia-futebolcarnaval à complexidade da experiência turística contemporânea. IN: PANOSSO NETTO, A.; TRIGO, L.G.G. (org.). Turismo na América Latina: casos de sucesso. Assis-SP: Triunfal Gráfica e Editora, 2016. Pp.81-112. 